УДК 577.21:582.739:581.143

S.N. NIFANTOVA, I.K. KOMARNICKIY, N.V. KUCHUK

Institute of Cell Biology and Genetic Engineering

National Academy of Sciences of Ukraine, Kyiv

E-mail: sveta@iicb.kiev.ua

\section{OBTAINING OF TRANSGENIC FRENCH BEAN PLANTS (PHASEOLUS VULGARIS L.) RESISTANT TO THE HERBICIDE PURSUIT BY AGROBACTERIUM- MEDIATED TRANSFORMATION}

The transgenic plants of French bean (Phaseolus vulgaris) resistant herbicide Pursuit and kanamycin have been obtained. The genetic transformation was carried out with Agrobacterium tumefaciens strain LBA4404 containing binary vector carrying mutant ahas/als and selective nptII genes. Integration of the transgenes into plant genome was confirmed by polymerase chain reaction.

C S.N. NIFANTOVA, I.K. KOMARNICKIY, N.V. KUCHUK, 2011
Introduction. Herbicide Pursuit belongs to imidozolinone group and inhibits the acetolactate synthase enzyme involved into biosynthesis of hydroxyaminoacids such as valine, leucine, isoleucine. The mechanism of imidozolinone effects has lots in common with the one of sulfonylurea $[1,2]$. Plant resistance to this herbicide is caused by the acetolactate synthase (ahas/als) gene mutation that consequently changes proline for serine in position 197 [3].

The imidasolinone-resistant plants were obtained by mutagenesis [4] as well as transferring of the mutant acetolactate synthase gene to plant tissues [5-8]. Sulfonylurea-resistant mutants were obtained for Nicotiana tabacum [9], Arabidopsis thaliana [4], soybeans [10], Brassica napus [11], Datura innoxia [12], Zea mays [13]. Transgenic sulphonilurea-resistant Nicotiana tabacum plants were obtained as well [14]. We have also obtained the Pursuit-resistant transgenic plants of pea (Pisum sativum L.) [15].

French bean (Phaseolus vulgaris L.) belongs to the leguminous plants. Genetic transformation is expected to improve its edible qualities and form the new plant properties such as resistance to diseases, herbicides, pests and abiotic stresses. There are only few reports describing transgenic French bean production. Genetically transformed plants of French bean were developed by the method of particle bombardment [16]. The obtained plants contained gus and neo genes, which were co-introduced with methionine-rich $2 \mathrm{~S}$ albumine gene isolated from Brazil nut and antisense sequence of $A C 1, A C 2, A C 3$ and $B C 1$ genes from bean golden mosaic geminivirus. Simultaneously transgenic plants of French bean with gus reporter gene were obtained by particle bombardment [17]. Tepary bean (Phaseolus acutifolius L. Gray) transgenic plants containing gus, nptII genes and arceline protein gene conferring resistance to insects (Coleoptera, Bruchidae) were obtained via Agrobacterium tumefaciens-mediated transformation [18]. There is one report describing the production of French bean transgenic «hairy roots» carrying $g u s$ and $g f p$ genes [19].

The purpose of this work was to develop Agrobacterium-mediated transformation protocol and to construct transgenic French bean (Phaseolus vulgaris L.) plants resistant to herbicide Pursuit.

Materials and methods. Aseptically growing French bean (Phaseolus vulgaris L.) plants of «Krasnoperaya», «Nezhnost» and «Chudesnaya» varieties were used for this study. 


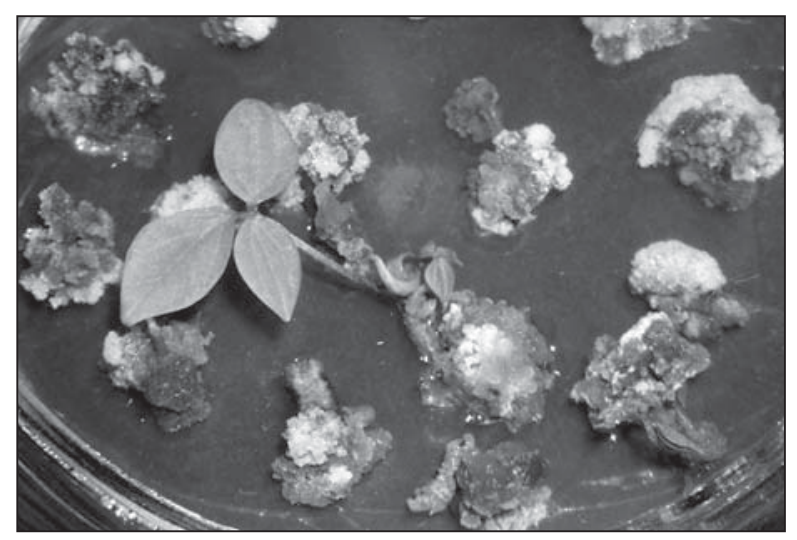

Fig. 1. The selection and regeneration processes of French bean variety «Krasnoperaya» on the regeneration B5 medium with $2 \mathrm{mg} / 1 \mathrm{BAP}, 0.2 \mathrm{mg} / 1 \mathrm{IAA}, \mathrm{Ag}_{2} \mathrm{~S}_{2} \mathrm{O}_{3}, 40 \mu \mathrm{g} / 1$ Pursuit and $100 \mathrm{mg} / \mathrm{l}$ kanamicyn

The number of regenerating and transgenic lines of bean

\begin{tabular}{l|c|c}
\hline \multirow{2}{*}{ Lines } & \multicolumn{2}{|c}{ The number } \\
\cline { 2 - 3 } & obtained & $\begin{array}{c}\text { transgenic } \\
\text { plants }\end{array}$ \\
\hline Climbing bean «Chudesnaya» & 0 & 0 \\
Climbing bean «Nezhnost» & 5 & 3 \\
French bean «Krasnoperaya» & 13 & 10 \\
\hline
\end{tabular}

Genetic transformation was carried out with Agrobacterium tumefaciens strain LBA4404 containing mutant ahas/als gene and neomycine phosphotransferase II selectable (nptII) marker gene in the binary vector $\mathrm{pCB} 004$.

Plant leaves and stems were cut into explants and put onto basal B5 [20] agar solidified medium with $1 \mathrm{mg} / 12,4-\mathrm{D}, 0.2 \mathrm{mg} / 1 \mathrm{BAP}$ and $0.5 \mathrm{mg} / \mathrm{l}$ adenine for callus initiation. After $2-3$ weeks the calli were transferred to the same but liquid medium and Agrobacterium tumefaciens overnight grown culture was added in proportion 1/100. Co-cultivation was held on at $22{ }^{\circ} \mathrm{C}$ in the dark for 48 hours.

Callus was infiltrated, washed by sterile water and put onto the agar solidified nutrient B5 medium containing $400 \mathrm{mg} / \mathrm{l}$ cephotoxime for bacteria elimination and $40 \mu \mathrm{g} / \mathrm{l}$ Pursuit and $100 \mathrm{mg} / \mathrm{l}$ kanamycin. In 4-6 weeks the selected callus clones were put on the regeneration medium with B5 basal components, $2 \mathrm{mg} / 1 \mathrm{BAP}, 0.2 \mathrm{mg} / \mathrm{l} \mathrm{IAA}$, $\mathrm{Ag}_{2} \mathrm{~S}_{2} \mathrm{O}_{3}$ and the same selective agents. $\mathrm{Ag}_{2} \mathrm{~S}_{2} \mathrm{O}_{3}$ was added as $5 \mathrm{mg} / 1 \mathrm{AgNO}_{3}+248 \mathrm{mg} / 1 \mathrm{Na}_{2} \mathrm{~S}_{2} \mathrm{O}_{3}$.
Regenerated shoots were transferred onto hormone free B5 medium for root formation. Fully formed plants were put from aseptic conditions into soil in humidity chamber for 2-3 days. Finally, plants grown in greenhouse formed flowers and seeds after manual pollination.

Primers for amplification of ahas/als gene sequence f.5'-CCGAGCTCACACATTTCTCG-3', r. 5'-AAGGTTCTGATAATCACCGG-3' and the ones for amplification of $n p t I I$ gene f. 5'-GAGGCTATTCGGCTATGACTG-3'，r. 5'-CAAGCTCTTCAGCAATATCACG-3' were used for polymerase chain reaction (PCR). 300-bp fragment was amplified by PCR for ahas/als gene and 647bp fragment was amplified for nptII gene. The sample of $10 \mathrm{ng}$ of total plant DNA extracted by CTAB method was used for this reaction [21]. The PCR reaction was carried out on Eppendorf Mastercycler personal and the mixture in total volume of $50 \mu \mathrm{l}$ contained of $39 \mu \mathrm{l}$ with template DNA, $1 \mu \mathrm{l}$ of each the primers $(50 \mu \mathrm{M}), 4 \mu \mathrm{l}$ dNTPs $(2.5 \mathrm{mM}), 5 \mu \mathrm{l} 10 \times$ Taq buffer and $1 \mu \mathrm{l}$ with 1 unit of Taq polymerase Template DNA was initially denatured at $95^{\circ} \mathrm{C}$ for 3 min. Reaction followed by 35 cycles of PCR amplification under the following conditions: $45 \mathrm{~s}$ denaturation at $95{ }^{\circ} \mathrm{C}$, $30 \mathrm{~s}$ primer annealing at $50{ }^{\circ} \mathrm{C}$ for ahas/als gene and $56^{\circ} \mathrm{C}$ for $n p t I I$ gene, and $45 \mathrm{~s}$ primer extension at $72{ }^{\circ} \mathrm{C}$. Final 6 min incubation at $72{ }^{\circ} \mathrm{C}$ was allowed for complementation of the fragment. After 40-cycled amplification the samples were fractionated in $2 \%$ agar gel in the field voltage of $100 \mathrm{~V} / \mathrm{cm}$ for 2 hours in TBE-buffer. The gels were stained by ethidium bromide.

Results and discussion. The selective concentration of herbicide Pursuit for callus tissues of all the studied bean varieties was specified to be $40 \mu \mathrm{g} / \mathrm{l}$. The herbicide effect on callus tissues caused the stop of their biomass increasing and led to death at last.

Genetic transformation was carried out with Agrobacterium tumefaciens harbouring pCB004 plasmid for transferring mutant ahas/als gene and selective $n p t I I$ gene as described in «Material and Methods» section. Selection was done on the agarsolidified callus inducing medium with $40 \mu \mathrm{g} / \mathrm{l}$ Pursuit and $100 \mathrm{mg} / \mathrm{l}$ kanamicyn. Selected callus clones were put on the regeneration medium with the same selective substances and $\mathrm{Ag}_{2} \mathrm{~S}_{2} \mathrm{O}_{3}$. Silver thiosulfate is known for its antiethylene effect that 


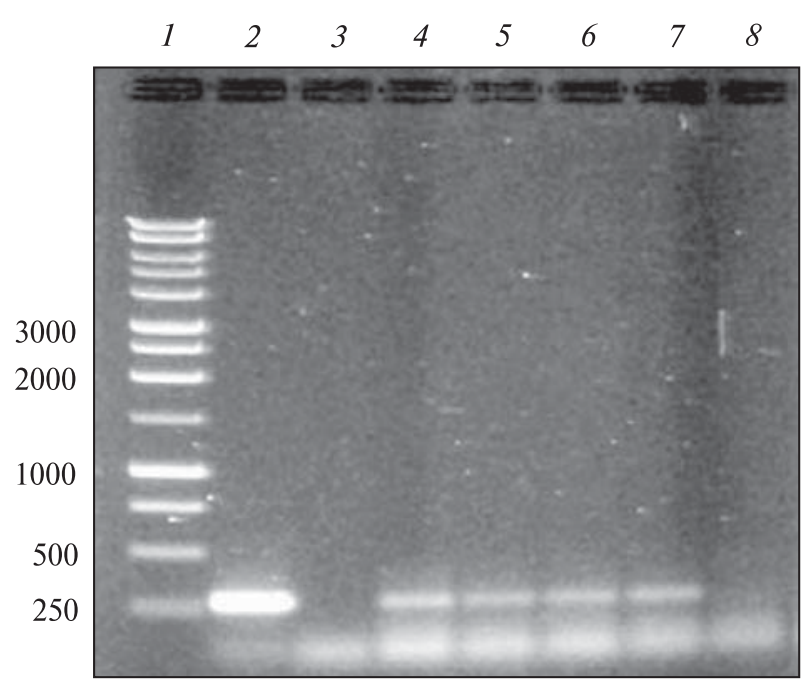

Fig. 2. PCR amplification of ahas/als gene fragment from plant DNA of the transformed lines of beans: 1 - molecular marker, 2 - positive control (plasmid pCB004), 3 - untransformed line, 4-7-transformed lines (4-R8, 5- R6, 6- R7, 7 - R9), 8 - negative control without DNA

led to promotion of the regeneration capacity for calli. [22]. In 2-3 months some of the selected calli formed dark green regenerating spots that were used for further shoot regeneration (Fig. 1). The regeneration frequencies varied from 1.7 to $7.5 \%$. The results of the regenerating lines selection are shown in the Table.

There were no morphogenesis or callus formation observed for control (not treated with Adrobacterium) explants on selective medium with kanamicyn and Pursuit for all tested French bean cultivars. Due to the poor regeneration ability of bean «Chudesnaya» we didn't manage to obtain the transformants.

All the obtained regeneration lines were analysed using PCR analysis for the ahas/als and nptII transgenes. There were 3 regeneration lines of «Nezhnost» variety and 10 lines of «Krasnoperaya» variety that had positive signals after PCR analysis. The results for ahas/als gene are shown on the fig. 2 and for $n p t I I$ gene on the fig. 3. The transformation frequencies varied from 2.8 to $17.4 \%$.

The obtained transgenic French bean plants were rooted and then bloomed in vitro though they did not form seeds. But we managed to get seeds in greenhouse after manual pollination (Fig. 4).

The present work is to the best of our knowledge the first report where transgenic plants of French

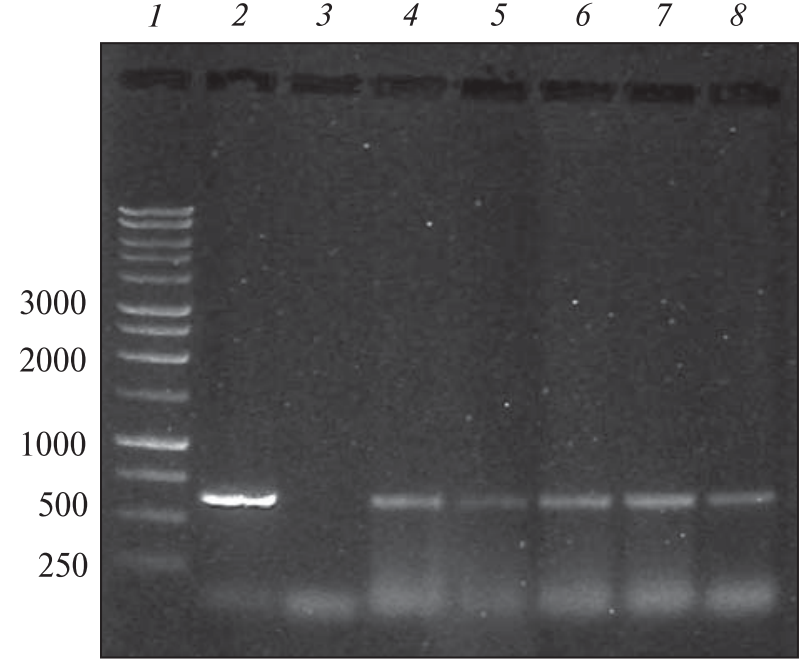

Fig. 3. PCR-analysis of gene $n p t I I$ presence in plant DNA of the transformed lines of beans: 1 - molecular marker, $2-$ positive control (plasmid pCB004), 3 - the untransformed line, 4-8-transformed lines (4-R8, 5- R6, 6- R7, 7$\mathrm{R} 9,8-\mathrm{R} 10)$

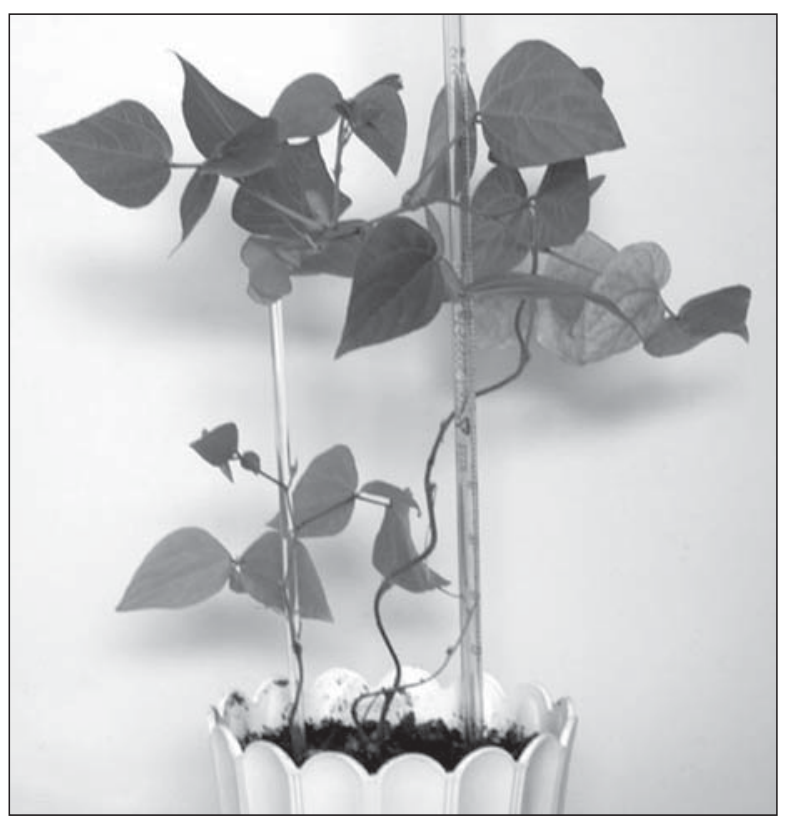

Fig. 4. The transgenic French bean plant of «Krasnoperaya» variety in the soil

bean have been obtained through Agrobacterium tumefaciens transformation. Developed protocol allowed us to get Pursuit resistant bean plants. Early we reported about regeneration of Pursuitresistant transgenic plants of pea (Pisum sativum 
L.) [15]. This communication confirms the efficiency of the worked-out protocols for genetic transformation of some leguminous plants.

\author{
С.Н. Нифонтова, \\ И.К. Комарницкий, Н.В. Кучук \\ ПОЛУЧЕНИЕ ТРАНСГЕННЫХ \\ PURSUIT-УСТОЙЧИВЫХ РАСТЕНИЙ ФАСОЛИ \\ ОБЫКНОВЕННОЙ (РHASEOLUS VULGARIS L.) \\ МЕТОДОМ АГРОБАКТЕРИАЛЬНОЙ \\ ТРАНСФОРМАЦИИ
}

Получены трансгенные растения фасоли обыкновенной (Phaseolus vulgaris), которые содержат ген ahas/als, обусловливающий устойчивость к гербициду Pursuit. Генетическую трансформацию осуществляли с использованием штамма Agrobacterium tumefaciens LBA4404, который содержит плазмиду рСВ004, с мутантным геном ahas/als и маркерным геном nptII, обусловливающим устойчивость к канамицину. Селектирован ряд устойчивых к гербициду Pursuit и канамицину линий. Интеграция перенесенных генов в растительный геном доказана при помощи метода полимеразной цепной реакции.

\section{С.М. Нифонтова,}

I.К. Комарницький, М.В. Кучук

\section{ОТРИМАННЯ ТРАНСГЕННИХ РОСЛИН КВАСОЛІ ЗВИЧАЙНОЇ (PHASEOLUS VULGARIS L.), СТІЙКИХ ДО ГЕРБІЦИДУ PURSUIT, ЗА ДОПОМОГОЮ АГРОБАКТЕРІАЛЬНОЇ ТРАНСФОРМАЦІЇ}

Отримано трансгенні рослини квасолі звичайноі (Phaseolus vulgaris), які містять мутантний ген ahas/als, що обумовлює стійкість до гербіциду Pursuit. Генетичну трансформацію проводили за допомогою штаму Agrobacterium tumefaciens LBA4404 з використанням плазміди рСВ004, яка містила мутантний ген ahas/als та маркерний ген nptII, що обумовлює стійкість до канаміцинсульфату. Інтеграція перенесених генів у рослинний геном доведена за допомогою полімеразної ланцюгової реакції.

\section{REFERENCES}

1. Hattori J., Rutledge R., Labbe H., Brown D., Sunohara G., Miki B. Multiple resistance to sulfonylureas and imidazolinones conferred by an acetohydroxyacid synthase gene with separate mutations for selective resistanse // Mol. Gen. Genet. - 1992. - 232. - P. 167-173.

2. Li Z., Hayashimoto A., Murai N. A sulfonylurea herbicide resistance gene from Arabidopsis thaliana as a new selectable marker for production of fertile transgenic rice // Plants. Plant Physiol. - 1992. - 100 (2). - P. 662 668

3. Yadav N., McDevitt R.E., Benard S., Falco S.C. Single amino acid substitutions in the enzyme acetolactate synthase confer resistance to the herbicide sulfometuron methyl // Proc. Nat. Acad. Sci. USA. - 1986. - 83. P. 4418-4422.

4. Haughn G.W., Somerville C. Sulfonylurea-resistant Arabidopsis thaliana // Mol. Gen. Genet. - 1986. 204. - P. 430-434.

5. Haugh G.W., Smith J., Mazur B., Somerville C. Transformation with a mutant Arabidopsis acetolactate synthase gene renders tobacco resistant to sulfonylurea herbicides // Mol. Gen. Genet. - 1988. - 211. - P. 266271.

6. Lee K.Y., Townsend J., Tepperman J., Black M., Chui C.F., Mazur B., Dunsmuir P., Bedbrook J. The molecular basis of sulfonylurea herbicide resistance in tobacco // EMBO J. - 1988. - 7(5). - P. 1241-1248.

7. Pogrebnyak N.Ya., Kravets O.A., Shisha E.N., Gleba $Y u . Y u$. Production of cell lines and plants of potato resistant to herbicide effect // Cytology and Genetics.1992. - 26. - P. 50-55 (in Russian).

8. Smith J.K., Mauvais C.J., Knowlton S., Mazur B.J. Molecular biology of resistance to sulfonylurea herbicides // Proc. ACS Symp. Biotechnol. Crop Protect. Washington, 1988. - P. 25-36.

9. Ray T.B. Site of action of chlorsulfuron: inhibition of valine and isoleucine biosynthesis in plants // Plant Physiol. - 1984. - 75(3). - P. 827-831.

10. Sebastion S.A., Chaleff R.S. Soybean mutants with increased tolerance for the sulfonylurea herbicides // Crop Sci. - 1987. - 27. - P. 948-952.

11. Swanson E.B., Herrgesell M.J., Arnoldo M., Sippell D.W., Wong R.S.C. Microspore mutagenesis and selection : Canola plants with field tolerance to the imidazolinones // Theor. Appl. Genet. - 1989. - 78. - P. 525530.

12. Saxena P.K., King J. Herbicide resistance in Datura innoxia: cross-resistance of sulfonylurea-resistant cell lines to imidazolinones // Plant Physiol. - 1989. 86(3). - P. 863-867.

13. Shaner D.L., Anderson P.C. Mechanism of action of the imidazolinones and cell culture selection of tolerant maize // Biotechnology in plant science / Eds M. Zaitlin, P.R. Day, A. Hollaender. - New York : Acad. press, 1984. - P. 287-300.

14. Gabard J.M., Charest P.J., Iyer V.N., Miki B.L. Crossresistance to short residual sulfonylurea herbicides in transgenic tobacco // Plants. Plant Physiol. - 1989. 91. - P. 574-580.

15. Nifantova S.N., Simonenko Yu., Komarnitskii I.K., Kuchuk N.V. Production of transgenic pea (Pisum sativum L.) plants resistant to the herbicide pursuit // Cytology and Genetics. - 2005. - 39, № 2. - P. 16-21 (in Russian).

16. Aragao F.J.L., Barros L.M.J., Brasileiro A.S.M., Ribeiro S.G., Smith F.D., Sanford J.C., Faria J.C., Rech E.L. 
Inheritance of foreign genes in transgenic been (Phaseolus vulgaris L.) co-transformed via particle bombardment // Theor. Appl. Genet. - 1996. - 93. P. $142-150$.

17. Jae W.K., Minamikawa T. Transformation and regeneration of French been plants by the particle bombardment process // Plant Sci. - 1996. - 117. - P. 131138.

18. Zambre M., Goossens A., Cardona C., Van Montagu M., Terryn N., Angenon G. A reproducible genetic transformation system for cultivated Phaseolus acutifolius (tepary bean) and its use to assess the role of arcelins in resistance to the Mexican bean weevil // Theor. Appl. Genet. - 2005. - 110 (5). - P. 914-924.

19. Estrada-Navarrete G., Alvarado-Affantranger X., Olivares J.E., Diaz-Camino C., Santana O., Murillo E., Guillén G., Sánchez-Guevara N., Acosta J., Quinto C., Li D.,
Gresshoff P.M., Sánchez F. Agrobacterium rhizogenes transformation of the Phaseolus spp.: a tool for functional genomics // Mol. Plant Microbe Interact. 2006. - 19(12). - P. 1385-1393.

20. Gamborg O.L., Miller R.A., Ojima K. Nutrient requirements of suspension cultures of soybean foot cells // Exp. Cell Res. - 1968. - 50, № 1. - P. 151-158.

21. Murray M.J., Thompson W.E. Rapid isolation of high molecular weight DNA // Nucl. Acids Res. - 1980. № 19. - P. 4321-4325.

22. De Block M. Genotype-independent leaf disc transformation of potato (Solanum tuberosum) using Agrobacterium tumefaciens // Theor. Appl. Genet. - 1988. 76. - P. 767-774. 